\title{
Negotiation of Identity in K R Meera's Hangwoman
}

\author{
Hari M G \\ Assistant Professor, Department of English and Humanities, Amrita University, \\ Coimbatore, India. Orchid: oooo-0oo3-0508-8112. Email: harimgo9@gmail.com \\ Received May 15, 2017; Revised June 28, 2017; Accepted July 02, 2017; Published August 11, 2017.
}

\begin{abstract}
This paper explores the negotiation of identity in K R Meera's novel Hangwoman, in the light of Michel Foucault's deliberations on power, subjectivity, and critique. The novel's layered delineation of the way power shapes subjectivity, and its insightful detailing of the scope for resistance the very process itself entails, echoes the thoughts of Foucault. Meera's protagonist exudes an exemplary resilience when she confronts multi-faceted subjugation. The resistance that she makes is characterised by a resourcefulness to actively engage in the mechanics of power and to remake her own sense of identity. Thus power, as depicted in the novel, is a force that creates 'identities' and at the same time a productive network which gives room for remoulding identities. The paper, also, discusses the protagonist's gritty resistance to the hyperrality of the postmodern visual media.
\end{abstract}

Keywords: Hangwoman, K R Meera, Foucault, Subjectivity, Critique, Power

\section{Introduction}

Negotiation of identity in post-liberalised India has been fraught with a gamut of highly volatile socio-cultural issues. On the one hand, there are the feudal ethos very much intact in the cultural palimpsest, and on the other, there is the postmodern space of identities in a flux. In such a cultural milieu, literary representations of individual agency formation demands great imagination and creative vigour. This is exactly what the Malayalam novelist K R Meera does in her novel, Hangwoman. The political resistance in terms of subjectivity that the central character in this novel does with grit is an exemplary case of gaining agency even in the midst abject subjugation. This paper, attempts to look closely at the political underpinnings of the individual resistance of Meera's protagonist in the light of Michel Foucault's expositions of how power negotiations that happen in a private space.

K R Meera is a major Malayalam novelist and short story writer. Her novel, Arachar which came out in 2012 became quite a sensation in Malayalam literary scene and it went on to win the Central Sahitya Akademi award. In 2015, Penguin brought out the English translation of this novel, titled, Hangwoman. It was shortlisted for the prestigious DSC award for the best novel from South Asia. Although, Hangwoman is a Malayalam novel, the themes that it deals with are panIndian. It depicts the multi-layered othering in Indian society and it also reflects the predicaments of contemporary India. The novel stands out for its close portrayal of the life of a marginalised woman and her resistance to the subjugation that is meted out to her. So, the central concern of this novel is the physics of power that strangles subjectivity and the heroic resistance to such a

(C) AesthetixMS 2016. This Open Access article is published under a Creative Commons Attribution Non-Commercial 4.0 International License (http://creativecommons.org/licenses/by-nc/4.0/), which permits non-commercial re-use, distribution, and reproduction in any medium, provided the original work is properly cited. For citation use the DOI. For commercial re-use, please contact editor@rupkatha.com. 
situation. These two strands of the novel makes it apt to be read in the light of the concepts of Foucault, who has left behind an enduring legacy of decoding power by closely analysing the dynamics of different socio-cultural discourses and institutions. Throughout his career, Foucault was preoccupied with how human subjectivity is embedded in the labyrinth of power, or rather, as Ellen $\mathrm{K}$ Feder puts it, "the assignment of subject positions whereby individuals are assigned roles in the social world" (Feder, 2011). But Foucault's theorisation of power is not deterministic; he contends that power underscores the existence of human freedom - had individuals not been free, there would not have been any need for the different establishments to condition them. Foucault makes this explicitly clear in an interview he gave in 1984:

"there cannot be relations of power unless the subjects are free...if there are relations of power in every social field it is because there is freedom everywhere." (Foucault, The Ethics of Care for the Self as the Practice of Freedom, 1994, p. 17)

Hence, for Foucault, human subjectivity is shaped within the grids of power; but this process gives room for the exercise of human freedom. The 'art of navigating power relations' (Foucault, What is Critique?, 1997, p. 45) is what Foucault calls 'critique'. Through critique an individual distances herself from the dictums of power and exercises her freedom even as she is not completely outside the domain of power. Literary works which depict heroic acts of 'navigating power' are not only significant but also revolutionary in their scope.

\section{Hangwoman}

The novel set in Bengal tells the tale of a woman belonging to a family of executioners. The novel's title points to its central problematic. The executioner's job which is traditionally done by men is given to a woman. The central character of this novel, Chetna, who is assigned the execution of a recent convict becomes a crucible of different power strands. On the one hand, she belongs to a family living in abject poverty, and on the other hand, she is thrown into a world of politics, beaurocracy and sensation driven media. Since the execution is a much discussed issue in Bengali media and is a politically contentious issue, she is forced to face a world of social complexities embedded in different power structures. By the sheer positioning of the central character in a space fraught with power, the novelist creates room for a delineation of how power negotiations happen in private lives.

Chetna's family has been doing the executioner's job for many centuries. She grows up listening to the tales that her grandmother tells her and those stories are far from the innocent tales one would tell a child. Rather, they are part of the sordid realities of a past that haunts not just her family, but the entire nation. The city of Kolkata which was the epicentre of power in this country for many years is for her family a narrative in their family folklore:

"We have been here for ever so long - long before the Europeans divided Kolkata into White and Black towns, before the Basaks and Seths set up villages besides the Hoogly." (Meera, 2015, p. 19)

Since they were the executioners during the time when Bengal was a princely state, and then during the colonial period and after independence, the family tales give insights about the mechanics of power. By embedding the historical narrative of Kolkata within a family history, Meera's portrayal of the city is both 'acutely observed, almost anthropological, in its minute detailing' (Das, 2014). Throughout the novel, Meera presents Chetna as a character who has innate understanding of the mechanics of power. By being witness to the formation of a city, the family has lived insights into how power operates at the macro as well as the micro-level and could see the undercurrent of power as a common thread in the socio-cultural discourses of the 
pre-colonial, colonial and post-colonial India. 'Deeply rooted in the city's over three-hundredyear-old history, demonstrating a sure-footed sense of its culture', (Menon, 2014) and armed with a clear insight into the twisted logics of power, she is negotiating her identity in a space where the 'hyperreality' of the postmodern India coexist with centuries of power formation. Her identity becomes a problematic terrain when she agrees to be the executioner of a recent convict. The unpalatabality of a female executioner in popular culture as well as the sensation craving media's exploitation of the issue make her face unusual situations.

\section{The Mechanics of Subjugation}

The affront that Chetna faces is from many sides. Her agency is taken for granted in many of the occasions where she has to confront those who are more privileged than her. The most blatant insults come from Sanjeev Kumar Mitra, the journalist who makes an agreement with her father which forces her to give a series of interviews regarding the execution. Right in their first meeting he grabs her and tell her with audacity that he wants to 'fuck her hard' (Meera, 2015, p. 92). The sad and ironic predicament that she has to put up with is the fact that despite Mr. Mitra showing scant respect and affection for her, she get into a complex relationship wherein love and lust get entangled with violence. All throughout the negotiations that she has regarding the execution and the interviews she gives for his channel, she is never given a space to voice her opinion. On top of all these, she is made a piece of entertainment in his show, being paid to perform as he commands. The hyperreality of digital world where images do not signify anything in particular and have just the surface reality is brought out here. As Baudrillard notes, it is a world where images do not represent reality, but replace it:

"It is no longer a question of imitation, nor of reduplication, nor even of parody. It is rather a question of substituting signs of the real for the real itself; that is, an operation to deter every real process by its operational double, a metastable, programmatic, perfect descriptive machine which provides all the signs of the real and short-circuits all its vicissitudes. Never again will the real have to be produced: this is the vital function of the model in a system of death, or rather of anticipated resurrection which no longer leaves any chance even in the event of death. A hyperreal henceforth sheltered from the imaginary, and from any distinction between the real and the imaginary, leaving room only for the orbital recurrence of models and the simulated generation of difference." (Baudrillard, 1988, p. 172)

Ten years since India's economic liberalisation, i.e., from 2000 onwards, news channels began cropping up in almost all Indian languages. Even a cursory acquaintance in the way news is 'generated' in these channels, would tell one how faithfully it follows the paradigm of the hyperreal digital world which, as pointed out by Baudrillard, does not even attempt to represent reality. News is consciously created as entertainment. Chetna is made a pawn in this play of empty signifiers. Her private space is always infringed upon and desecrated. When she is presented in television, the entertainment value lies in mainly two factors. 1. She is an important character in the drama surrounding the impending execution. For the news channels, the uncertainty of the event gives it the excitement like that of a very tight cricket match. And her presence is needed to flare up this excitement. 2. The novelty of a woman becoming an executioner. As a gendered subject, the role of the executioner does not go well with the 'performative' of feminity. By both accounts, she becomes an image that is over-signified with everything and anything that can make the television discourse on the execution a 'spectacle'.

Caught up in such a situation where she has to deal with the most humiliating exploitation by a man whom she loves and hates at the same time and in a predicament in which 
she has to find a way out of the complexities of a hyperrreal world, Chetna is confronting power squarely. But the power that she confronts is not in concrete forms; it is quite discursive. The subtle nature of the power discourses is explicit in the novel. Nowhere in the novel, she is overtly restricted by power, but always pushed into a space of subjugation through subtexts of the discourses surrounding her. The subject position that is assigned is never asserted overtly, but always covertly. This nuanced portrayal of power, makes the novel fall in line with Foucault's views on power. As Nancy Hartsock contends, for Foucault, "Power is not to be seen as a single individual dominating others or as one group or class dominating others". But rather, it is a sort of control brought to effect through a network of discourses:

"Power is never localised here or there, never in anybody's hands, never appropriated as a commodity or piece of wealth. Power is employed and exercised through a net-like organisation." (Hartsock, 1990, p. 162)

The production of power also entails the space to resist. It is a 'productive network which runs through the whole social body', for which repression is not the only function (Foucault, Power/knowledge: Selected interviews and other writings, 1972-1977, 1980, p. 35). This 'productive' quality of power carries the seed of resistance within. It is by actively engaging with the 'networks' of power that one exercise agency; and this is what Chetna succeeds in, as the novel progresses. As Nandini Nair contends:

"For Meera, Hangwoman isn't merely about creating a compelling character and an unusual plot, instead it is about remedying historical wrongs, about writing "her story" and shattering gender stereotypes" (Nair, 2014).

What makes her character quite striking is the fact that in spite of all the subjugation she is able to create a distance from a total submission and shows guts to revolt.

The 'effects of truth' that a subject comes across are varied. Each relationship entails an idiosyncratic power negotiation. Multiple relationships that one is engaged in, inevitably lead to a multiplicity of power negotiations, as well, which in turn results in the creation of different subject-positions. However, these subject positions are not rigid and fixed. Keeping in spirit with the productive quality of power that Foucault brought out in his theoretical expositions on power, his views on subject formation are anchored on the creative possibilities that it offers. He views the process as one wherein there is enough space to create the 'self' or rather, the space to have different relationships with oneself. Foucault's makes this quite clear in an interview:

"You do not have the same type of relationship to yourself when you constitute yourself as a political subject who goes to vote or speaks at a meeting and when you are seeking to fulfil your desires in a sexual relationship. Undoubtedly there are relationships and interferences between these different forms of the subject; but we are not dealing with the same type of subject. In each case, one plays, one establishes a different type of relationship to oneself. And it is precisely the historical constitution of these various forms of the subject in relation to the games of truth which interests me." (Foucault, The Ethics of Care for the Self as the Practice of Freedom, 1994, p. 15)

\section{Critique and Subjectivity}

Hangwoman is essentially the narrative of Chetna's creation of a different relationship with herself and her social world. She gains agency by refusing to completely identify with the subjectpositions she is offered. It is resilience despite all the humiliations she has to undergo that makes her subjectivity free, at least to some extent. This distance one creates with respect to power 
mechanisms is what Foucault calls 'critique'. In his article, "What is Critique?", Foucault defines critique as "movement by which the subject gives himself the right to question truth on its effects of power and question power on its discourses of truth." (Foucault, What is Critique?, 1997, p. 47) The narrative of truth that power generates has to be questioned to 'critique' it. At the same time, the role of 'truth' in validating a power system has to be understood. Chetna's responses to power, in fact, constitutes critique. In a desperate attempt to gain back subjectivity and agency, she, often defies the rules of the power game and refuses to believe the 'truth' embedded in power grids. Her responses to Sanjeev Kumar Mitra in the latter part of the novel display this defiance and lack of fear towards power. Although, initially she feels helplessness when Mitra sexually assaults her, gradually, she develops a grip over the situation. When she readily goes to his room willing to have sex, she finds her male partner weak to encounter her forthright nature:

"The training he had received from this world as a man reminded him that sex was the obvious outcome in such a situation. But he was afraid to take a woman who had walked into his bedroom of her own free will." (Meera, 2015, p. 328)

She explicitly asks why men bring in a violent colour to their sexuality. Sanjeev Kumar's violence is just a mask to cover his cowardice. By taking on this cowardice directly she gets outside the clutches of power that strangles her. She does not run away from the gaze of power, instead decides to look at it straight in the eye. She emerges as a subject who has refused to become a 'docile body'. As Foucault contends, the power exercised on the body is always in the form of a strategy (Foucault, Discipline and Punish: The Birth of the Prison, 1979, p. 29) It is by disrupting this strategy that she retaliates to the dictums of power. She is, in fact, changing the grammar of a discourse in which she had little space to negotiate.

Another striking fact about Chetna's reconstruction of her subjectivity in the latter part of the novel is that she is completely aware of the politics that is implicit in her relationship with the world. She cannot help thinking about the systemic injustice that is all pervasive. As a woman who knows the history of her country, she is also conscious of the fact that post-independence India is not much different from the colonial India. She has the objectivity to know that she is not just a 'victim' in this system, but has a complicit role in keeping it as it is. That is why when she Mr. Mitra bombards her with a question regarding the ethical correctness of her job as an executioner, she does not lose her ground. She cannot isolate the task of the executioner from the panorama of injustice that happens in the world. To preach ethics and justice, without being aware of the complicit role that everyone plays in systemic injustice, is to be mocked at, for her:

"In no country has the death penalty the number of crimes or criminals. Given this, is the state not committing a major transgression against humanity by denying a human being the right to stay alive? By expressing your willingness to take up such a line of work, Chetna, aren't you too participating in this transgression?

"Are we not party every single day, in many ways, to the crimes of others?...All of it...from dawn to dusk...how many are the injustices we bear...how many we let past ourselves, not uttering a word...that is the biggest crime." (Meera, 2015, p. 212)

She could see through the ethical vacuity in the pseudo-concern for humanity. This clarity with regard to the underlying ethics of the events that happen around her gradually develops in her as the novel progresses. The way she positions herself with respect to each situation makes her character one that has a dynamic subjectivity in a Foucaultian sense. The choices that she makes in the situations that she finds herself, also realign her identity in terms of the relation to 'self'. 
The dynamism of her subjectivity springs forth from her vibrant repositioning of her identity in the societal matrix and from the alteration in the relationship she has with her 'self.

Through critique, Chetna is winning for herself the dignity of speaking and acting freely even as she is within the ambit of power. As K Santhosh notes: '

"Meera's icily sardonic black-edged prose strangles tentacles of male arrogance and cocks a snook at the growing media invasion of individual's privacy" (Santhosh, 2014).

It is by acting and positioning herself differently with respect to power that she attains this freedom. Such a mode of response constitutes 'critique' in the Foucaultian sense. Judith Butler in her article, "What is critique? An Essay on Foucault's Virtue" says that more than anything else, critique entails a freedom to question and the act of making ethical choices:

"What becomes especially important for Foucault in this domain, is to try to think the problem of freedom and, indeed, ethics in general, beyond judgment: critical thinking constitutes this kind of effort." (Butler, 2002, p. 216)

Coming out of the quotidian conceptions of ethics, Chetna strives to live by her own ethical standards. The freedom that she exercises stands out for its non-teleological nature. It is not with a definite aim to shape her subjectivity in a particular way or to materialise something in the external world that she rebels. Rather, her freedom manifests as the exploration of the possibilities of new ways of being and the search for new ways of relating to the world. She refuses to accept the 'absoluteness' of the established narratives. Being aware of the plasticity of the discursive space that she is placed in, she can afford to dismiss the absolute claims of the established narratives without much difficulty. Foucault regards such an understanding as a prerequisite for freedom to be exercised:

"One of the meanings of human existence - the source of human freedom - is never to accept anything as definitive, untouchable, obvious, or immobile. No aspect of reality should be allowed to become a definitive and inhuman law for us." (Foucault, Read Me: Foucault Interview - 'In a Sense, I am a Moralist, 2017)

\section{Conclusion}

Meera presents the trajectory of the evolution of Chetna's character with a lot of psychological insight. She moves from a woman who is not very different from a gendered subject in India to an authentic human being who is resourceful enough to act and speak without the fetters of her highly controlled social identity. The novelist does this job in an adept manner which is possible only for a writer who has command over her craft. Meera brings the reader's attention to the present, and thereby makes a close delineation of the nuances of each situation and a detailing of different psychological states. The close attention that she gives the present, strips it off all the certainties that are usually condition our perception. In Meera's creative world, the present moment exist as a criss-cross of different strands of thought and emotion and as a space of many possibilities. The thrust here is the ontological dimensions of such an investment of attention in the present. In this respect too, the novel echoes the thoughts of Foucault. Meera's characterisation is in tune with the link that Foucault made between the 'virtual fracture' of the present and 'a space of freedom and transformation':

"I would like to say something about the functions of any diagnosis concerning the nature of the present. It does not consist in a simple characterisation of what we are but, instead - in managing to grasp why and how that-which-is might no longer be thatwhich-is. In this sense, any description must always be made in accordance with these 
kinds of virtual fracture which open up the space of freedom understood as a space of concrete freedom, i.e. a space of possible transformation." (Foucault, Critical Theory/Intellectual History, 1990, p. 22)

Television interview with Sanjeev Kumar Mitra after the execution, turns out to be a telling statement of the radical quality that Chetna's subjectivity has acquired over the course of the events. As a demonstration of the execution and as a detailed account of the responses of the convict, Mr. Mitra arranges the facilities to enact the execution inside the studio - a final celebration of the event, making it an ultimate spectacle. Playfully luring him to offer himself as the condemned in the demonstration of the execution, she ties the rope around his neck and gives him a taste of the pain that he so callously refers to in his lengthy speeches on television, also offering him a glimpse of death. Ironically, the entertainment value of the programme will increase on the event of a near death experience of a TV anchor. The fact that she is capable of doing such an act, knowing very well that it is being viewed by thousands of people is indicative of the subjective freedom that she is not ready to forsake at any cost. Her state of mind that the novelist details quite vividly is that of a subject who has embraced the flux like nature of her mind and the world. Her experience of seeing a person die before her fills her mind with a sort of uncanny courage that would never let her down:

"Just like the gallows, I burst out laughing. The grains of sand made a grating sound inside the silk cloth. I had it tight with hands slimy with death. Thus my name and my life became undying in Bharat and the whole world, in the name of love, soil, and death. I knew well that no one would stop me. Rain, soil, light and history stood waiting for me." (Meera, 2015, p. 420)

When the novel ends, Chetna is not a woman who is baffled by a world she does not understand, but one who is less affected by it. Her lack of fear towards the machineries of subjugation is the outcome of an adventurous inner journey, traversing all the complexities of a world mired in power. The choices she makes on the way lead her to a space where she could reimagine her subjectivity. Falling in line with Foucault's positive definition of freedom, her subjectivity becomes an act of bringing forth new dimensions of existence as opposed to a mere rebellion against the existing power structures. The fact that Meera contextualises such a heroic tale within the grim realities of modern India, makes Hangwoman one of most remarkable novels in contemporary Indian literature.

\section{Funding Information}

This project does not have any funding and no funding was received for publication.

\section{Works Cited:}

Baudrillard, J. (1988). Simulations and Simalucra. In M. Poster (Ed.), Selected Writings (pp. 166-184). Stanford: Stanford University Press.

Butler, J. (2002). What is Critique? An Essay on Foucault's Virtue. In D. Ingram (Ed.), The Political Readings in Continental Philosophy (pp. 212-226). London: Routledge.

Das, S. (2014, October 6). KR Meera borrows liberally from the mystique of the Dhananjoy hanging in Hangwoman. Indian Express. 
Feder, E. K. (2011). Power/Knowledge. In D. Taylor (Ed.), Michel Foucault: Key Concepts (p. 59). Durham: Acumen Publishing Limited.

Foucault, M. (1979). Discipline and Punish: The Birth of the Prison. New York: Vintage.

Foucault, M. (1980). Power/knowledge: Selected interviews and other writings, 1972-1977. (C. Gordon, Ed.) New York: Pantheon.

Foucault, M. (1990). Critical Theory/Intellectual History. In L. Kritzman (Ed.), Michel Foucault: Politics, Philosophy, Culture, Interviews, and Other Writings 1977-1984 (pp. 17-46). London: Routledge.

Foucault, M. (1994). The Ethics of Care for the Self as the Practice of Freedom. In J. W. Rasmussen (Ed.), The Final Foucault (pp. 1-20). Cambridge: MIT Press.

Foucault, M. (1997). What is Critique? In S. L. Hochroth (Ed.), The Politics of Truth (pp. 23-82). New York: Semiotext(e).

Foucault, M. (2017, April 18). Read Me: Foucault Interview - 'In a Sense, I am a Moralist. Retrieved from www.criticaltheory.com: http://www.critical-theory.com/read-me-foucault-interview-in-a-sense-i-ama-moralist/

Hartsock, N. (1990). Foucault on Power: A Theory for Women. In L. Nicholson (Ed.), Feminism/Postmodernism (pp. 157-75). London: Routledge.

Meera, K. R. (2015). Hangwoman. New Delhi: Penguin.

Menon, D. (2014, November 1). Kerala in the World: The roots of K R Meera's Deeply Local Cosmopolitanism. The Caravan: the Journal of Politics and Culture.

Nair, N. (2014, July 18). Telling her Story. Business Line.

Santhosh, K. (2014, December 6). And thereby Hangs a Tale. The Hindu Literary Review.

Hari M G is Assistant Professor in the Department of English and Humanities, Amrita University. He holds a $\mathrm{PhD}$ in English Literature from IIT Kharagpur. He is a recipient of research fellowships such as UGC-JRF, and Institute Fellowship, IIT Kharagpur. His areas of research include Continental Philosophy, Bhakti Poetry, Indian English Poetry, and Bhasha Literatures. Orchid id: http://orcid.org/oooo-0oo3-0508-8112. Email - harimgo9@gmail.com 